Dept of Bacteriology,

Faculty of Medicine Assiut University.

\title{
PATHOLOGICAL AND IMMUNOLOGICAL CHANGES IN RABBITS INFECTED WITH INFECTIOUN BOVINE RHINOTRACHEITIS VIRUS (IBR)
}

(With one Table and 7 Figures)

By

\author{
E.K. NAFIE; R.H.M. DOGHAIM*; M.EL-NIMR **; \\ A.E. AGAG ***and MONA. HAMOUDA* \\ * Faculty of Vet. Med., Cairo University. \\ ** Faculty of Med. Assiut University. \\ *** Animal Health Research Institute.
}

(Received at 10/3/1996)

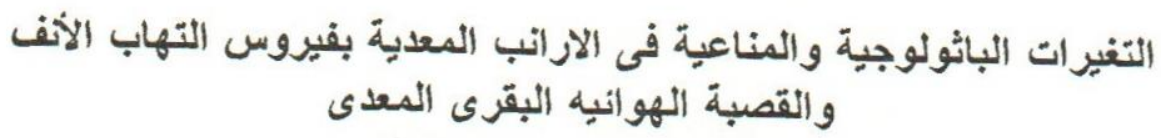

عداد نافع، روحية دوغيّ، مدب النسر، أحد عجاح، هنى حوده

أستخدم فى هذه الار اسه اربعون ارنبا نيوزيلندى خاليه من الامر اض قسمت اللى ثـلاث مجاميع:

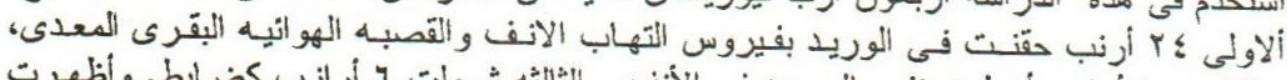

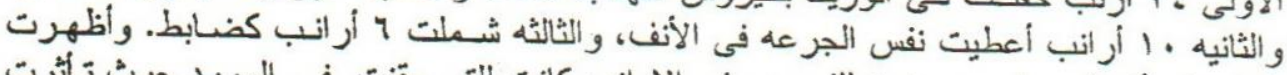

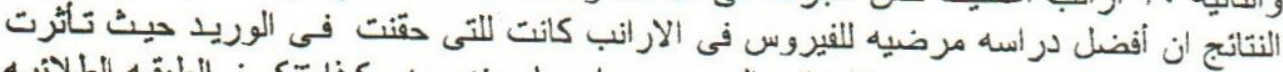

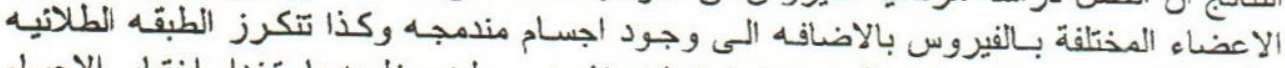

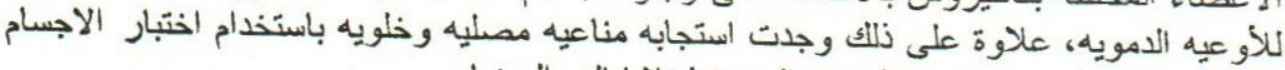
المناعيه المتعادله واختبار عامل منع الهجرة لخلايا الدام البيضاء.

\section{SUMMARY}

Forty pathogen free newzealand rabbits were used in this study. They were divided into 3 groups: the first group consisted of 24 infected intravenously with IBR virus. The second of 10 infected intranasally and the third of 6 as uninoculated control. The intravenous route proved to be the best one for studying the pathogenesis of IBR virus infection in rabbits. The virus affects 
various organs with intranuclear inclusion bodies as well as endotheliosis. Moreover there is both humoral as well as cell-mediated immune responses as detected by Serum neutralization test (SNT) and leukocytic migration inhibitory factor (MIF) respectively.

Key words: IBR-Infection of rabbits-Patholoy-Immunoloy.

\section{INTRODUCTION}

IBR primarily affects cattle causing respiratory, genital and nervous manifestations (Kahrs. 1977). Other animals such as goats, swines and water buffaloes are naturally infected. Serological studies indicated that infection could occur in other species (Afshar and Fadjbakhsh, 1970). The virus was not pathogenic for mice and guinea pigs (Merchant \& Pacher, 1967; Armstrong et al., 1961). It was pathogenic for rabbits by skin scarification, intracerebral and corneal routes (Persechino et al., 1965) as well as by intratesticular and intradermal routes (Armstrong et al., 1961).

Yet we still need a suitable laboratory animal for studying the pathogenesis as well as the diagnosis of IBR virus infection and evaluation of the vaccines.

\section{MATERIAL and METHODS}

\section{I- Material:}

1- Rabbits: Fourty rabbits (Newzealand) each of $1.8-2 \mathrm{~kg}$ body weight were used. The rabbits were fed a standard diet and sulfaquinoxaline for one week prior to virus infection. Thirty four were used for experimental infection while six left as uninoculated controls.

2- Virus: IBR (Japanese strain-758) was propagated and titrated in vero cell culture according to the method of El-Nakashly et al . (1985).

3- Cell culture: Both bovine and vero cell cultures were propagated and maintained according to Youngner (1954).

\section{II- Methods:}

1- Infection of rabbits: The rabbits were divided into two groups: the first of 24 and the second of 10 rabbits. Each animal of the first group was intravenously inoculated with $1 \mathrm{ml}$. of the virus $\left(10^{5} \mathrm{TCID}_{50}\right)$, while each animal of the second group was infected by the intranasal instillation of the same dose of virus. Each animal of the control group received one $\mathrm{ml}$. of strile saline solution. The animals were kept under observation with daily recording of the body temperature. Two animals of the inoculated group 
were slaughtered every 48 hours, while from the control group one was sacrified every 4 days.

\section{2- Collection of Samples:}

A- Heparinized blood: At predetermined intervals, uncoagulated blood was collected from each animal to be used for separation of leukocytes and mononuclear cells.

B- Serum: In addition, at predetermined intervals, blood was collected from each animal separately, left to clot and serum stored at $-20^{\circ} \mathrm{C}$ till used.

C- Tissue specimens: Tissue specimens were collected from both infected and control animals, prepared for histopathological studies and stained with the following stains:

-hematoxline and eosin (Harris, 1898).

- Lendrum's phloxin tartrazine (Clayden, 1971).

- Crossman's stain (Culling, 1963).

\section{3- Serological tests:}

A-Serum neutralization test: According to Hafez and Frey (1973).

B-Leukocyte migration inhibition factor (L.I.F.):

\section{RESULTS}

1- Clinical Symptoms: Only a mucopurulent discharge was observed from the nostriles of infected animals during the first week post-infection. As for temperature recording, results are presented in Fig (1).

2- Neutralization test: Results are shown in Fig (2).

3- Leukocytic Migration factor: Results are grouped in Fig (3).

4- Histopathological studies: Results of this investigation are presented in table (1) and Fig. (4).

\section{DISCUSSION}

Rabbits intravenously inoculated with IBR virus manifested a rise of temperature for 3 days (Fig. 1) This rise of temperature was attributed to the viraemic period in rabbits (Lupton et al., 1980 and Arab et al., 1984) and cattle (Miller, 1955). In addition there was a mucopurulent nasal discharge in both the infected groups. This was previously mentioned by Lupton and Reed (1979), which reflects the affinity of the virus to the respiratory system.

The immune response of rabbits to IBR virus was studied by conducting the SNT and Leukocytic migration inhibition factor. Results as presented in Figure (2) reveal an increase in antibody titre, reaching a maximum between 
20 and 24 days post-infection. The same finding was mentioned by Berrios et al. (1983). Results of the LMIF as detected in Fig. (3) reveal that there was an early response of leukocyte to the virus (by the 7 th day postinfection), even before the appearance of a humoral immune response. This test may be useful in case of vaccine evaluation. However Schollenberger and Prandata (1982) recommend both the cellular and humoral immune responses.

Histopathological studies revealed that, IBR virus affected different organs with a cellular destructive power especially the parenchymatous organs. The most characteristic lesions were necrobiotic changes (Liver, Kidney) together with infilteration of monocytes. According to Baker et al. (1960), these changes are greatly specific to IBR virus. They reported that the virus possesses a cytolytic effect on the host cell with release of the virus extracellularly infecting and destroying more cells. Thompson (1984) further added that immune response to the virus leads to morphological and functional alterations damaging the tissues where the virus grows resulting in progressive lesions and clinical disease.

The hyperplasia of the peribronchial lymphoid follicles may be explained as an immune defence mechanism against the virus. This explains also the hyperplastic proliferation of spleen lymphocytes, since the spleen is a site of antibody formation. Lesions in the central nervous system are typical. Lesions in viral affections (Okot Swangamoni and Kaminfola 1973). The presence of cowdry's intranuclear inclusion bodies is a manifestation of cellular infection with herpes viruses.

Lesions in the blood vessels indicate the endotheliotropism of the virus. Once more the hyperplasia of blood vessels could be attributed as a mean of defence mechanism of blood vessels against continuous irritation of the virus.

The previous results support the view that rabbits are susceptible to infection with IBR, producing both clinical and immunological responses. Hence this laboratory animal could be used with success in the evaluationof vaccines against this virus.

\section{ACKNOWLEDGEMENT}

The authors are grateful to Dr M.A.-El-SERGANY for his interest and advice. 


\section{REFERENCES}

Afshar, A. and Tadjbakhsh, H. (1970): Occurrence of precipitating antibodies to bovine herpes virus (infectious bovine rhinotracheitis) in sera of farm animals and man in Iran. J. Comp. Path., 80, 307-310.

Arab, R.; Marzouk, M.S.; Bakeer, A..M.; Karim, I.A. and El-Nakashly, S.A. (1984): Some studies o Infections Bovine Rhinotracheitis (IBR) virus in rabbits. Vet. Med. J., Vol. 32 (No. 3): 160-169.

Armstrong, C.J.A.; Preriera, H.G. and Andrewes, C.H. (1961): Observation on the virus of infectious bovine rhinotracheitis and its affinity with herpes group. Virobgy. 14: 276-285.

Baker, J.A.; Mcentee, K. and Gillespie, J.H. (1960): Effects of ifections bovine rhinotracheitis-infectious pustular vulvovaginitis (IBR/IPV) virus on newborn calves. Cornell. Vet., 50: 156-170.

Berrios, P.; Celedon, M.O.; Ibrra, L. and Acuna, M. (1983): Humoral immune response of rabbits inoculated with bovine herpes virus Type 2. Comparison of serum neutralization, Complement fixation, immune diffusion and passive haemagglutination tests. Vet. Bull., Vol., 53.

Clayden, E.C. (1971): Practical section cutting and staining 5th ed., churchil livingstone, Edinburgh, London.

Culling, C.F.A. (1963): Handbook of Histopathologica 2nd. Butter Worths, London.

El-Nakashly, S.A.; El-Danaf, V.A.; Hafez, M.A.M.; El-Shennawy, M.M.; Ikram Abd El-Karim and El-Nimr, M.M. (1985): Ifectious bovie rhinotracheitis amog newly-born calves in Egypt. 17th Arab, A. Veterinary Medical Copress, Cairo.

Harris, H.F. (1898): Cited by Carleto, M.A.; Drury, K.A.; Wallington, E.A. ad Camero, H. (1967): Carleton's Histological Technique. 4th Ed. Oxford University press ew Tork, Toronto.

Kahrs, R.F. (1977): Infectious bovine rhinotracheitis, A Review ad update. J.Am., Vet. Med. Ass., 171: 1055-1064.

Lupton, H.W. ad Reed, D.E. (1979): Experimental infection of Eastern cottontail Rabbits (Sylvilagus floriolanus) with Infectious Bovine Rhinotracheitis virus. Am.J. Vet. Res., Vol., 40: 1329-1331.

Lupton, H.W.; Bares, H.J. and Reed, D.F. (1980): Evaluation of the rabbits as a laboratory model for Infectious Bovine Rhinotracheitis virus infection. Cornell, Vet., 70: 77-95.

Merchant, I.A. and Packer, R.A. (1967): Veterinary Bacteriology and Virology, Ams, Iowa, U.S.A. 
Miller, N.J. (1955): Infectious necrotic rhinotracheitis in cattle. J. Am. Vet. Med. Ass., 126: 463-467.

Okot Bwangamoi, and Kamin Job, J.S. (1973): Observations on experimental infection with infectious bovine rhinotracheitis virus rabbits. Bull. Epiz. Dis. Afr., 21: 367-361.

Persechino, A.; Merucci, P. and Orfei, Z. (1965): Pathogenicita del virus della tracheite infectiva del vovino (IBR) SU animalida laboratorio. Nuova. Vet., 41: 213-222.

Scholknberger, A. and Prandota, J. (1982): Leukocyte migration test as an indicator of the immunogenicity of an attenuated IBR vaccine. Medycyna weterynaryna, 38: 645-647.

Thomson, R.G. (1984): General Veterinary Pathology. W.B. Saunders Company. Philadelphia, London, Toronto.

Younger, J.S. (1954): Monolayer tissue culture 1. Preparation and standerization of suspensions of trypsin dispersed monky kidney cells. Biol. Med. Proc., 85: 202-205.

Table. 1: Pathological lesions in various organs from rabbits experimentally infected with IBR virus.

\begin{tabular}{|c|c|c|c|}
\hline \multirow{2}{*}{$\begin{array}{l}\text { Organ } \\
\text { and /or } \\
\text { tissue }\end{array}$} & \multicolumn{3}{|c|}{ Main lesion in the examined organ from the respective group } \\
\hline & I & II & III \\
\hline Liver & $\begin{array}{l}\text { Congested-necrotic changes in the } \\
\text { first week, then multifocal to diffuse } \\
\text { areas of advanced necrosis-leukocytic } \\
\text { infilteration with lymphocytes and } \\
\text { round cells-focal hemorhage in the } \\
\text { necrotic areas. activation of kupffer } \\
\text { cells-the lesions subsided by the third } \\
\text { week Fig. (5) }\end{array}$ & $\begin{array}{l}\text { Some cells showed necrosis with } \\
\text { lymphocytic infiltration, others } \\
\text { dissociation with granularity and } \\
\text { vacuolarity of cytoplasm- } \\
\text { Activation of kupffer cells. } \\
\text { Macroscopically there was } \\
\text { congestion. }\end{array}$ & \\
\hline Kidney & $\begin{array}{l}\text { Congestion with focal depressed } \\
\text { areas. In the first week, early diffuse } \\
\text { necrobiotic chanes associated with } \\
\text { perivascular oedema-By the 2nd } \\
\text { week, complete necrosis of tubules, } \\
\text { infilteration with lymphocytes and } \\
\text { round cells infilteration. Some } \\
\text { tubules showed atrophoid, others } \\
\text { showed cystic dilatation Fig (6). }\end{array}$ & $\begin{array}{l}\text { Some tubules showed proteinous } \\
\text { dystrophy-Congestion of cortical } \\
\& \text { medullary blood vesseles are } \\
\text { observed. }\end{array}$ & \\
\hline
\end{tabular}




\section{Content Table 1:}

\begin{tabular}{|c|c|c|c|}
\hline \multirow{2}{*}{$\begin{array}{l}\text { Organ } \\
\text { and /or } \\
\text { tissue }\end{array}$} & \multicolumn{3}{|c|}{ Main lesion iin the examined organ from the respective roup } \\
\hline & I & II & III \\
\hline Lung & $\begin{array}{l}\text { Oedema with round cell infilteration } \\
\text { activation of septal cells \& } \\
\text { infilteration of monocytes narrowing } \\
\text { of the bronch al lumen-perivascular } \\
\text { oedema then narrowing of air spaces } \\
\text { with compansatory emphysema in } \\
\text { some air spaces. By third week, } \\
\text { lestions subside with endotheliosis. } \\
\text { Grossly the lung was congested Fig } \\
\text { (7). }\end{array}$ & $\begin{array}{l}\text { Lung congested- bronchitis- } \\
\text { perivascular cuffing of } \\
\text { peribronchial blood vessels. }\end{array}$ & \\
\hline Brain & $\begin{array}{l}\text { Perivascular oedema- heomorrhage } \\
\text { in brain ventricles focal gliosis- } \\
\text { intranuclear inclusions in neuron \& } \\
\text { glial cells- focal encephalomalacia. }\end{array}$ & $\begin{array}{l}\text { Minute focal areas of gliosis- } \\
\text { perivascular cuffin- degeneration } \\
\text { in some neurons. }\end{array}$ & \\
\hline $\begin{array}{l}\text { Adrenal } \\
\text { gland }\end{array}$ & $\begin{array}{l}\text { Minute necrotic foci in zona } \\
\text { fasculata-congestion of blood vessels- } \\
\text { then multiple focal to diffuse areas of } \\
\text { necrosis in zona fasculata, reticularis } \\
\& \text { medulla. Later severe necrosis, } \\
\text { infilteration of monouclear cells \& } \\
\text { intranuclear inclusion bodies. }\end{array}$ & & \\
\hline Spleen & $\begin{array}{l}\text { First hyperplasia of lymphoid } \\
\text { follicles-then depletion of } \\
\text { lymphocytes- activation of reticulo- } \\
\text { endothelial system. Finally, reticular } \\
\text { tissue replaced white pulp. Grossly it } \\
\text { is diffusely enlarged. }\end{array}$ & & \\
\hline Heart & $\begin{array}{l}\text { Hyaline degeneration and congestion } \\
\text { of blood vessls, then myomalacia } \\
\text { with leukoytic infilteration and } \\
\text { perivascular oedema. Finally lesions } \\
\text { subside except the mononuclear cell } \\
\text { infilteration. }\end{array}$ & $\begin{array}{l}\text { Myomalacia with infilteration of } \\
\text { mononuclear cells. Congestion of } \\
\text { blood vessls and hemorrhage in } \\
\text { endocardium. }\end{array}$ & \\
\hline Trachea & $\begin{array}{l}\text { Congestion of blood vessels and } \\
\text { oedema in lamina propria with } \\
\text { infilteration of mononuclear cells. }\end{array}$ & As in group I. & \\
\hline
\end{tabular}

I= Intravenous Group. II= Intranasal Group $\quad$ III = Control Group. 


\section{Assiut Vet. Med. J. Vol. 35 No. 70, July, 19996}

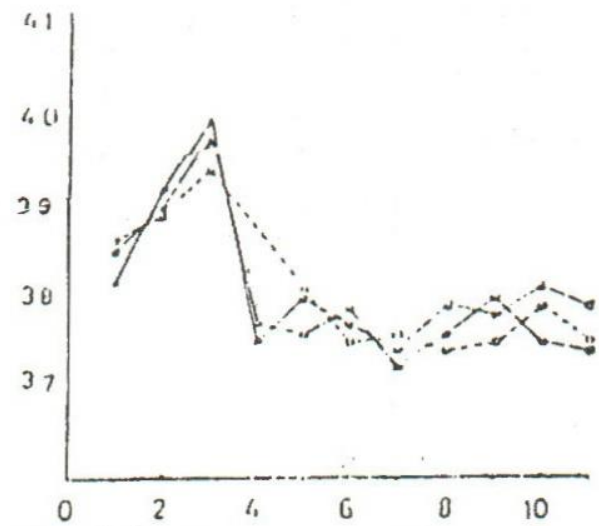

Fig. (1): Temperature deprens of rabbits infected intravenously with IBR virus.

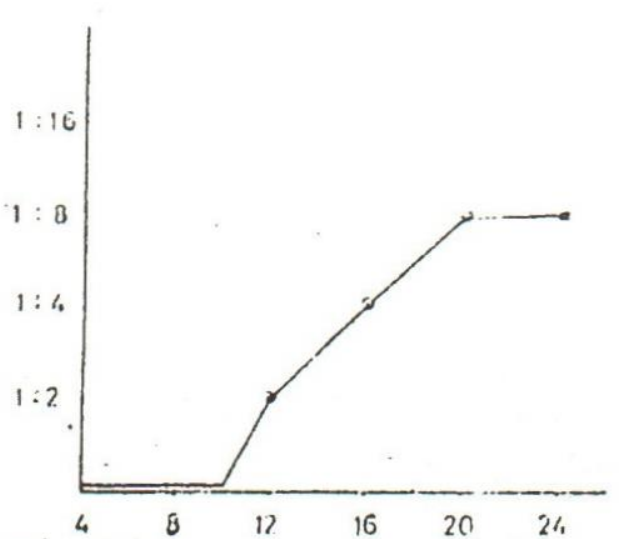

Fig. (3): iteutralizing Ab titres in sera from rabbits intravenously infected with IBii virus.

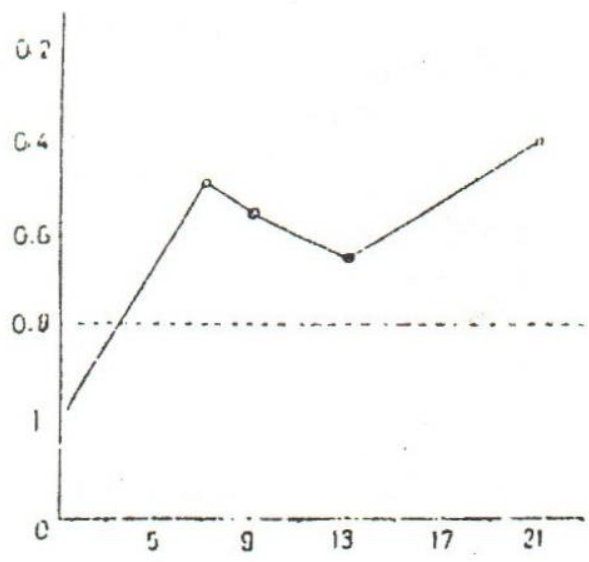

Fig. $\left(1_{+}\right)$: Migration index of lauks sey te: from rabhits intravenous!y infecteed with LUR vimus. 


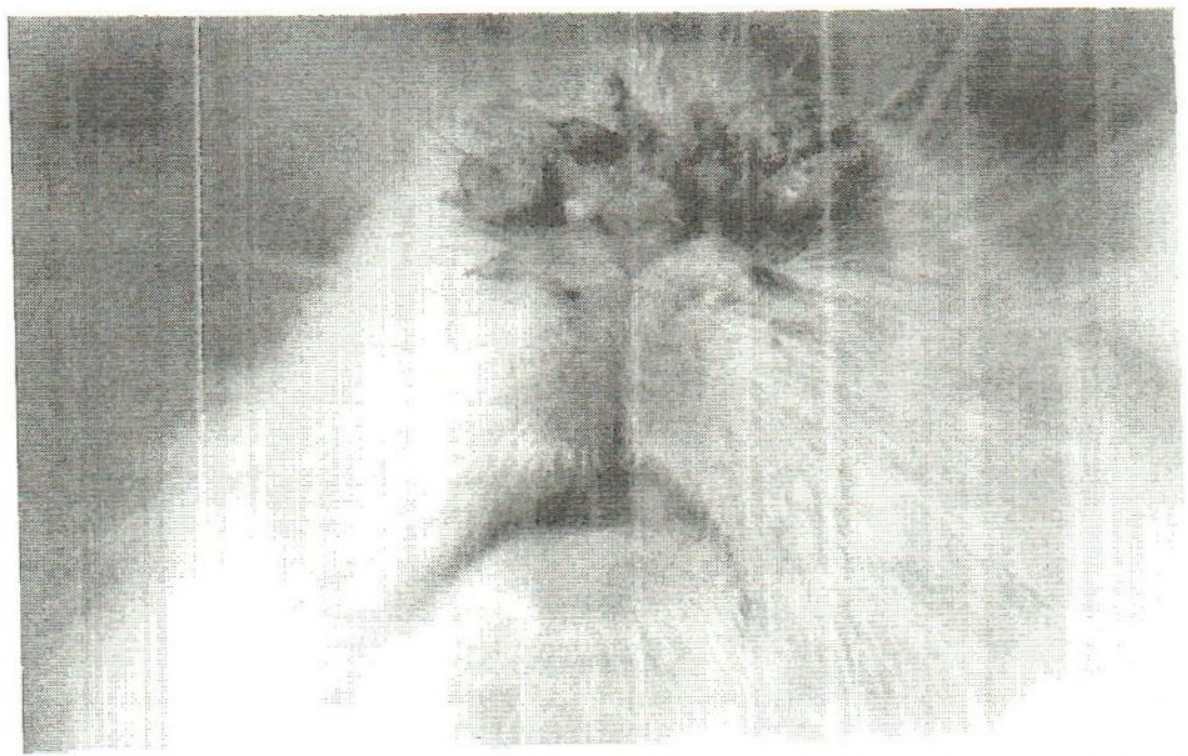

Fig. 2: Mucopurulent discharge from the nontrils of a rabbit after 5 days post intravenous infection with IBR virus.

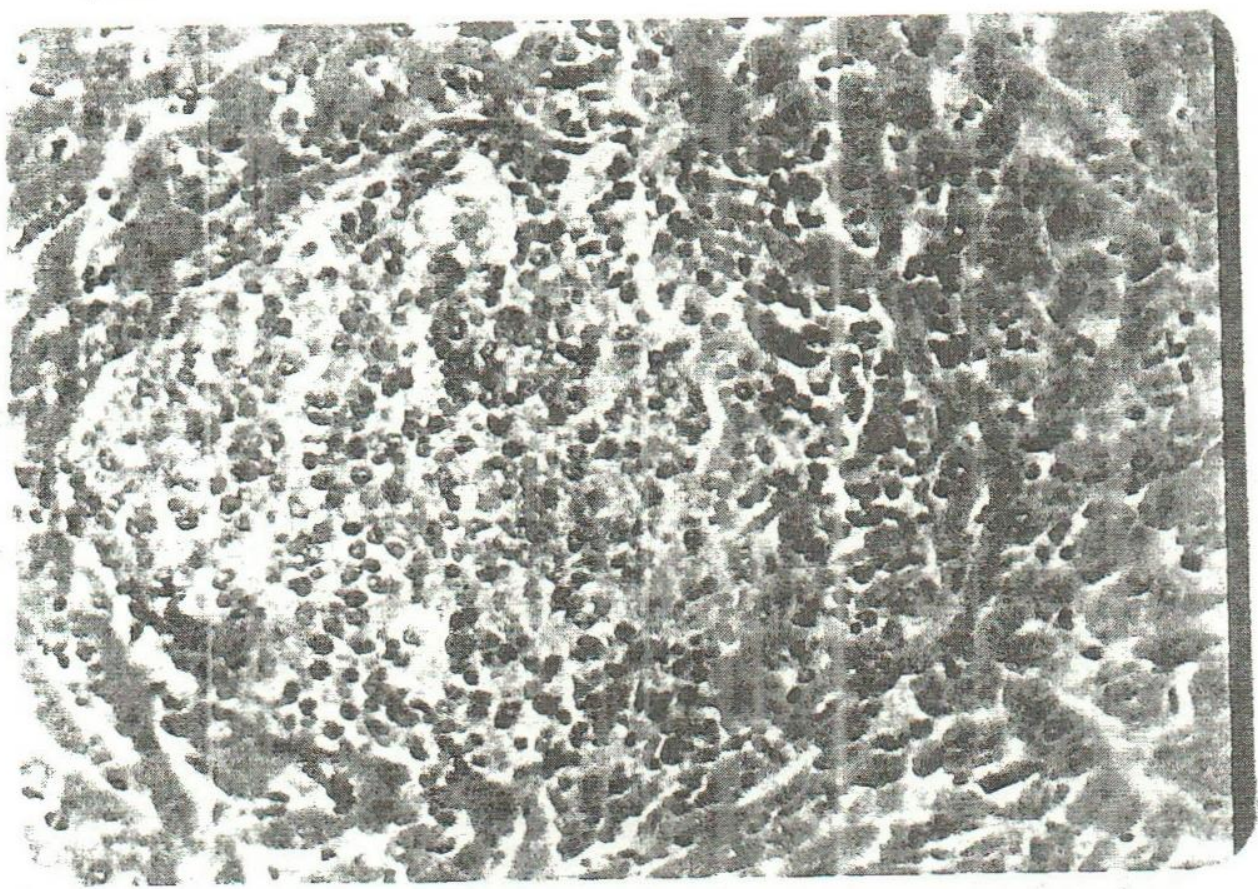

Fig. 5: Focal necortic area in liver represented by remnant of cells and surrounded by inflammatory cells.

H \& E X 375. 


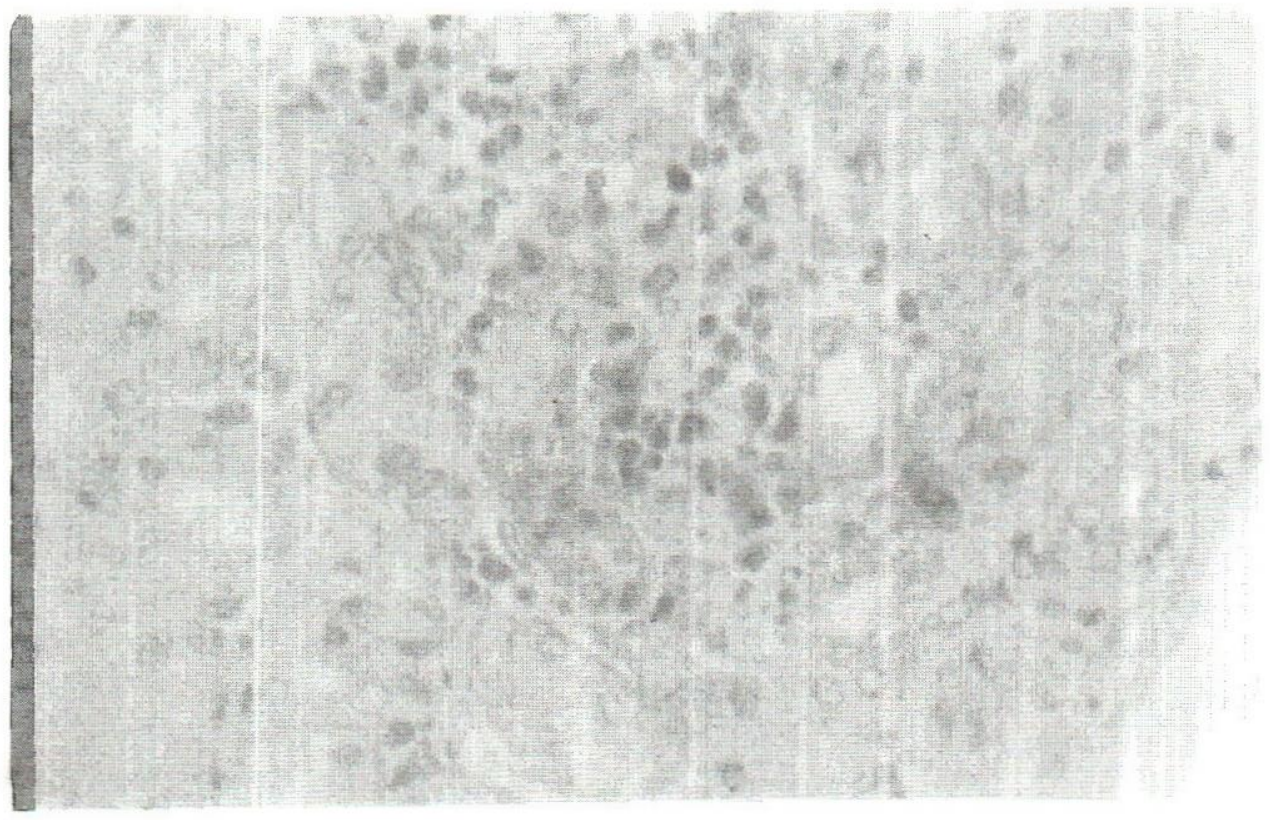

Fig. 6: Necrosis of renal tubules of kidney and infiltration of lymphocyte: and plasma cells. $H \& \mathbb{E} \times 600$.

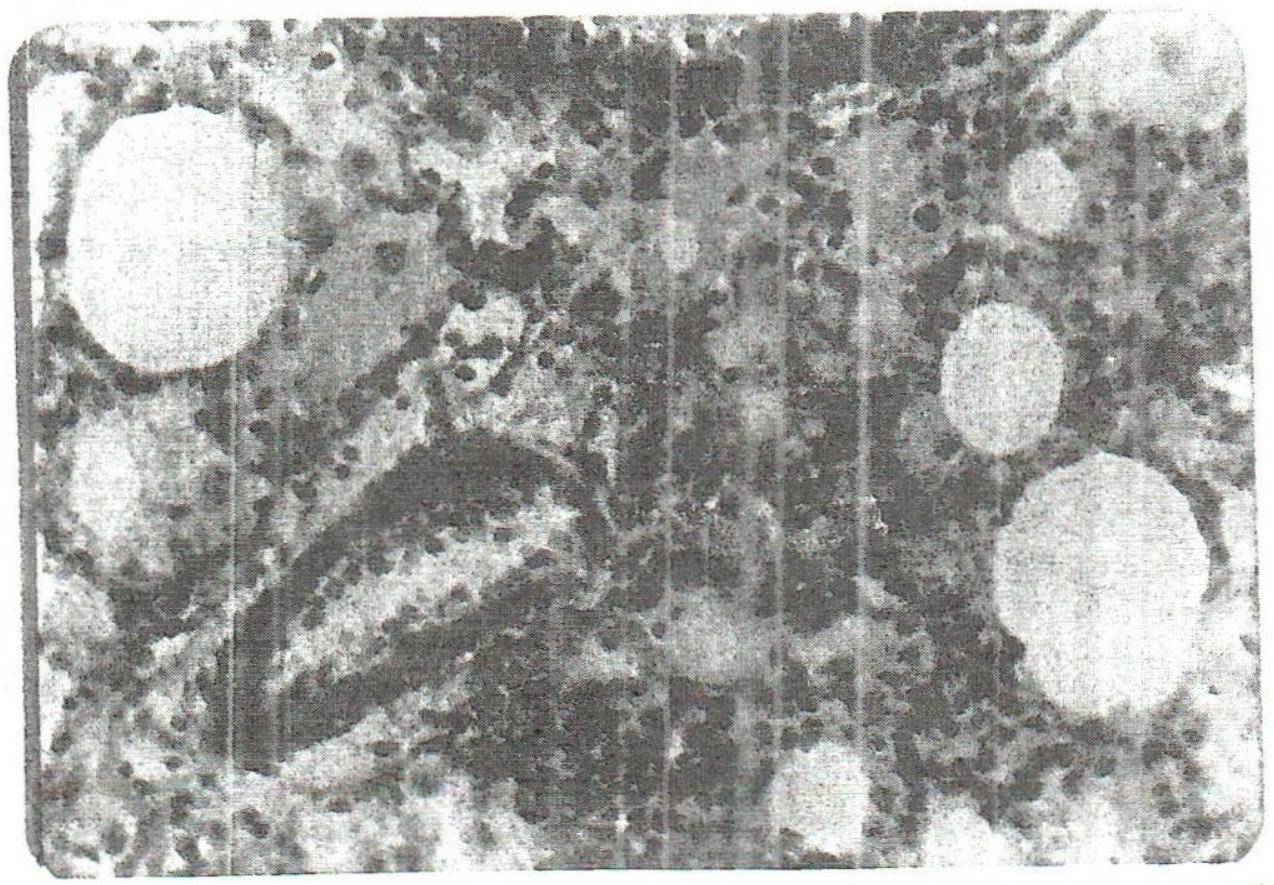

Fig. 7: Lung oedema and interstitial pnumonia characterized by activation of sepal cells and round cells infiltration. H \& E X 375. 